\title{
Chelva KanaganaYAKaM: A TRIBUTE ${ }^{1}$
}

\author{
SenAth WALter Perera
}

University of Peradeniya, Sri Lanka senath_p@yahoo.com

Received: 02-11-2015

Accepted: 03-11-2015

It was with profound sadness and deep shock that I learned of Chelva Kanaganayakam's passing at the age of 62 on $22^{\text {nd }}$ November 2014. He was driving home from Montreal to Toronto after being conferred the title Fellow of the Royal Society of Canada in recognition of his signal contribution to Canadian literary studies and culture, when he succumbed to a heart attack. "Kanags," as he was known at Trinity College, Kandy, Sri Lanka, excelled in studies and other pursuits. He played cricket for the school and also acted in plays. Since his father was Professor of Tamil at the University of Ceylon, Peradeniya, academe was in his DNA, as it were. Consequently, once he graduated from Kelaniya with English honours, he taught in the University of Jaffna for a while before completing his $\mathrm{PhD}$ at the University of British Columbia on a Commonwealth Scholarship. He was Professor in English at the University of Toronto when he died and Director of the Centre for South Asian Studies for several years.

Chelva was indubitably one of the most distinguished English academics produced by Sri Lanka in recent times. He published over six books and several articles pertaining to Sri Lankan and Postcolonial literature in English. He was equally well known for his research on Tamil Literature and his translations. He won several accolades but one which he especially cherished was receiving the Faculty of Arts and Science Outstanding Teaching Award-an honour indeed given that he was an expatriate working in the most prestigious English Department in Canada. Furthermore, those whose theses he supervised hold major academic positions across the world.

\footnotetext{
${ }^{1}$ An earlier version of this memorial tribute appeared in The Island on 28 November 2015.
} 
Despite living overseas for several years, Chelva never lost touch with Sri Lanka. He edited issues of Nethra for ICES, translated the Tamil novel Sandangu as Ritual for the Gratiaen Trust, contributed to The Sri Lanka Journal of the Humanities and Navasilu, was a plenary speaker at a SLACLALS conference and was working on a major article for Phoenix for me at the time of his demise. Chelva had the wonderful attribute of being a counsellor, guide, friend, benefactor and much more to people regardless of class, creed, or ethnic divide. To cite one example, he was looked after by a Sinhala ayah in his formative years. This ayah was very close to his mother and when she died in Canada, Chelva requested me to go to a village off Katugastota and personally communicate the news. He subsequently sponsored her pilgrimage to Dambadiwa, one of the most sacred Buddhist shrines in India, and after overcoming many administrative obstacles hosted her in Canada as well.

Because he was senior to me in high school, I did not know him well, initially, but when he learned through a mutual friend that I would be visiting Canada in 1999, he not only invited me to give a talk in Toronto but also insisted that I stay with him, his wife Thiru and two children. His home was my first port-of-call whenever I visited Toronto thereafter. The last time we met was at the ACLALS conference in Castries, St Lucia, in 2013, when he insisted once again on treating me to a home cooked meal even though he was living in a rented condominium for the duration of the conference. His hospitality was indeed legendary.

I shared the news of Chelva's death via academic networks and the response from his peers across the world was staggering. Prof. Amirjit Singh of the University of Ohio says, "he mentored students of all backgrounds - white and black, Sinhala and Tamil, Hindu and Muslim. And his students just adored him for his giving and supportive ways”; Dr Anupama Mohan who did her thesis under him declares, “On Facebook Chelva’s protégés are sharing their loss together and recalling vivid memories, and in a way, we are all bereft. Few people measured up to Chelva”; and according to Dr Michael Bucknor of Jamaica, a past Chair of ACLALS, "he was one of the kindest and most supportive academics I met as a young graduate student studying in Canada. With his and Victor's [Ramraj] passing, it seems like an entire epoch is coming to an end in Commonwealth/Postcolonial scholarship.”

It was Samuel Butler who said that "to die completely, a person must not only forget but be forgotten, and he who is not forgotten is not dead." Such words would bring little solace to a family that continues to grieve a year after his demise but given the numerous tributes paid to 
him since his passing, there can be no doubt whatsoever that Chelva's legacy as a respected academic and a prince among gentlemen will last for generations. He and I worshipped different gods but we shared a love of literature so I could do worse than invoke the Bard in trying to come-to-terms with his untimely death: "Then to the elements / Be free, and fare thou well!"

Senath Walter Perera is Senior Professor in English, University of Peradeniya, Chair of SLACLALS and the Gratiaen Trust, and a Bibliographical Representative for JCL. Formerly, he chaired the Commonwealth Writers Prize (Eurasia); edited SLJH, Navasilu and Phoenix; was articles editor for Postcolonial Text and on the inaugural Advisory Committee of the DSC Prize. His research has appeared in several publications worldwide. 